\title{
HUMAN RESOURCES PRACTICES AND ORGANIZATIONAL COMMITMENT: CONNECTING THE CONSTRUCTS IN A PUBLIC ORGANIZATION
}

\author{
HELOÍZA H. OLIVEIRA ${ }^{1}$ \\ (iD) https://orcid.org/0000-0002-4499-0291 \\ LUIZ C. HONÓRIO \\ (iD) https://orcid.org/0000-0001-8345-2587
}

To cite this paper: Oliveira, H. H., \& Honório, L. C. (2020). Human resources practices and organizational commitment: Connecting the constructs in a public organization. Revista de Administração Mackenzie, 21 (4), 1-27. doi:10.1590/1678-6971/eRAMG200160

Submission: Sept. 5, 2019. Acceptance: Mar. 2, 2020.

Centro Universitário Unihorizontes, Belo Horizonte, MG, Brasil.

\section{(c) $\mathbf{B Y}$}




\section{ABSTRACT}

Purpose: This article aims to describe and analyze the relationship between human resources practices and organizational commitment in a large public urban sanitation company.

Originality/value: It has been found that most human resources practices significantly influence organizational commitment, showing that the affective and normative commitment is the most affected and, on a weaker scale, there is the continuance commitment.

Design/methodology/approach: The survey was conducted with 349 employees whose formulated hypotheses were verified by multiple regression.

Findings: The results indicated a predominance of affective commitment of employees, greater agreement with the practice of human resources associated with benefits and disagreement with the career planning regarding the policies related to the internal selection process, selfdevelopment, compensation policy and the promotion process. The multiple regression analysis allowed to confirm the hypotheses postulated, revealing a more significant positive relationship between human resources practices with the types of affective and normative commitment when compared to the continuance commitment. Organizational commitment of the affective type proved to be positively influenced by the human resources practices associated with career planning and benefits, while the commitment of the normative type was positively more induced by the human resources practice related to training and development. Despite the fact that the article revealed results that contribute to the academy, future research must be carried out to improve the relationship between the constructs treated in this study.

\section{KEYWORDS}

Organizational commitment. Personnel management. Human resources practice. Working condition. Public organization. 


\section{INTRODUCTION}

The literature reveals that efficient human resources practices result in satisfactory and better quality performances. Among these, it can be highlighted the practices (career, security, compensation, performance evaluation, training and development, benefits, communication, participation in decisions) that reflect the human forces directed to the productive, managerial and strategic activities of an organization with a view to the demands required by complex and competitive environments (Collins \& Clark, 2003; Zavyalova, Kosheleva, \& Ardichvili, 2011; Darwish, 2013; Mithchell, Obeidat, \& Bray, 2013; Tian, Cordery, \& Gamble, 2016; Vermeeren, 2017; Katou, 2017; Krishnaveni \& Monica, 2018). In addition, studies reveal that higher levels of commitment also lead to satisfactory performance (Riketta, 2002; Jaramillo, Mulki, \& Marshall, 2005; Susanty \& Miradipta, 2013; Araújo \& Lopes, 2014; Maia \& Bastos, 2015; Jesus \& Rowe, 2015; Rocha \& Honório, 2015; La Falce, Paiva, Muylder, \& Morais, 2017).

The prevailing view on organizational commitment admits it as a multidimensional construct whose antecedents, correlated and consequent, are altered through the affective, normative and continuance bases, the latter also called instrumental. The affective and normative commitment implies involvement oriented by the desire and the moral obligation to remain in the organization, respectively, while the continuance commitment involves the need to stay in the organization since there is the possibility of high costs to leave it. The multidimensional approach recognizes that it is possible for the commitment types to happen at the same time and in different intensities, that is, an individual may wish to remain in the organization (affective commitment) and simultaneously believe that he must (normative commitment) or needs to act in this way (continuance commitment) (Meyer \& Allen, 1991; Meyer, Stanley, Herscovitch, \& Topolnytsky, 2002).

As for the relationship between the two constructs mentioned, on the one hand, there are studies that demonstrate effective human resources practices favoring greater commitment of employees to results, problems and organizational objectives (Whitener, 2001; Paul \& Anantharaman, 2004; Chew \& Chan; 2007; Wright \& Kehoe, 2008; Ordaz, Cruz, Ginel, \& Cabrera, 2011; Coetzee, Mitonga-Monga, \& Swart, 2014; Al Adresi \& Darun, 2017).

Whereas, some researches are not conclusive regarding the effect of organizational practices, for example, those of human resources, on the involvement with the organization (Reissner \& Pagan, 2013; Suan \& Nasurdin; 2014; Shuck, Twyford, \& Reio, 2014), or suggest that knowledge should 
advance regarding the relationships of implication between such constructs (Wollard \& Shuck, 2011; Karatepe \& Demir, 2014; Chen, 2017). In the context of service sector organizations, as is the case reported in this article, studies reveal that involvement with the organization becomes even more critical, due to the role that human resources practices play in employee satisfaction with work and in how the service it provides is perceived by users (Ashill \& Rod, 2011; Yeh, 2013; Rai, Ghosh, Chauhan, \& Meht, 2017).

There is a small amount of national research associating these constructs (Bandeira, Marques, \& Veiga, 2000; Cançado, Moraes, \& Silva, 2006; Borges, 2013; Demo, Martins, \& Roure, 2013; Scheible \& Bastos, 2013; Jesus \& Rowe, 2015), recognizing that there is a space for the addition of more studies and findings, similar or not to those already found, utilizing the same approach they used (Meyer \& Allen, 1991) and which remains the most widespread in national and international research on the topic.

Research also reveals that there are differences in how commitment is understood when considering the context under analysis. Studies argue that public sector employees exhibit behaviors and attitudes that differ from private-sector employees. For example, due to the predominance of bureaucratic cultures in the public sphere (Lyons, Duxbury, \& Higgins, 2006), it seems more evident that positive attitudes of involvement occur when more flexible management styles are adopted at work, compared to the private sphere (Zeffane, 1994).

Moreover, it is revealed that satisfaction with the receiving rewards tends to make the affective and normative commitment more pronounced among civil servants (Markovits, Davis, Fay, \& Dick, 2010). It is suggested by Markovits et al. (2010) that rational attitudes stand out among employees in the private sector because it is known what is expected of them in terms of performance and what they will receive in return for the effort at work. However, the expectation regarding the receipt of rewards, regardless of whether they are intrinsic or extrinsic, is higher in civil servants, making them more strongly committed when receiving them. Perhaps it is for this reason that the violation of the psychological contract of employment affects more the commitment of public employees in equivalence to private employees (Shahnawaz \& Goswami, 2011).

Finally, part of the literature argues that it is necessary to expand studies of organizational commitment in conjunction with correlates considered important for management, for example, human resources practices, decision-making processes, management of ethical issues, management styles, strategic planning, etc. (Wollard \& Shuck, 2011; Reissner \& Pagan, 2013; 
Karatepe \& Demir, 2014; Suan \& Nasurdin, 2014; Chen, 2017). This positioning, as well as the others previously described, served to support the following research question:

- What is evident from the relationship between human resources practices and the commitment of workers to an organization?

In view of the diversity of the theoretical and empirical positions so far defined, it is academically justified to fill the gap that suggests the need to continue conducting research that correlates human resources practices with organizational commitment, both in public and private spheres, aiming to raise data that can support, refute or add elements to the fields treated here. In short, we intend to contribute with this article to the debate and advancement of studies involving the context and the research constructs treated here. In the case of this article, the public context was the studied space, which served as an environment for the purpose of investigating the relationship of the influence between the human resources practices adopted by a large public company of urban sanitation in the state of Minas Gerais and the organizational commitment of its employees. The organization participating in the research was chosen because it has consolidated human resources practices, making the analysis possible in association with the dimensions that configure organizational commitment, according to the perspective of Meyer and Allen (1991).

\section{ORGANIZATIONAL COMMITMENT AND HUMAN RESOURCES PRACTICES: THEORETICAL-EMPIRICAL ELEMENTS}

At first, Meyer and Allen (1991) discussed the nature of the commitment from an attitudinal and behavioral perspective. Attitudinal commitment would constitute a process by which people would establish their relationship with the organization, realizing the congruence between their values and those of the organization. Behavioral commitment would be characterized as a process in which the subject would be attached to the organization and how to deal with it. Subsequently, the concept of commitment was broadened, being understood as a psychological state that can represent a desire, a need and/or an obligation for the purpose of staying in the organization (Meyer \& Allen, 1991).

Thus, three notions of involvement encompassed studies about the field: affection for the organization, the costs of leaving it, and the obligation 
to remain in it. Affection described the identification with the values disseminated by the organization and the efforts made by the individual to be part of it. As for the costs, it was understood that he associated himself with the elements that interfered in the decisions taken for the purpose of continuing or quitting his job. In relation to the obligation, this feeling was conditioned to moral standards that compelled the individual to remain in the organization, for example, gratitude and retribution for the investments made in favor of the employee (Meyer \& Allen, 1991).

Three types of commitment were identified to characterize the individual's involvement with the organization: affective, continuance and normative. The affective commitment refers to the employee's emotional bond and identification with the organization. The continuance commitment, also called instrumental, implying an awareness of the costs of leaving the organization, meaning to say that permanence would be necessary. Finally, the normative commitment, indicating that opting for employment was the result of an obligation because the individual believed that this should be done (Meyer \& Allen, 1991). Furthermore, these authors suggested that the three types of commitment could be experienced simultaneously and to varying degrees, that is, one might wish or need to remain in the job but feel little compulsion to be involved with the organization.

It is noteworthy that the model by Meyer and Allen (1991) represented an advance in research on the subject, but still incites a lack of conceptual consensus among a few scholars, by the way, because it is suggested that there is an overlap between the commitments of the affective and normative types. In other words, the feeling of retribution may be accompanied by affective attachment to the organization. Furthermore, it is suggested that the continuance basis is an antithesis of commitment (Moscon, Bastos, \& Souza, 2012). However, it is argued, by leading scholars on the topic, that few inconsistent studies have been carried out to test the relationship between the three types of commitment (Meyer et al., 2002), which is why the three-dimensional model of John Meyer and Natalie Allen remains a reference in the field.

In spite of considering that the current conjuncture of modern organizations demands survival in the market, it recognizes that people management is an essential factor in achieving this goal, as well as the employee's commitment to supporting this requirement. By definition, human resources practices encompass the procedures, methods and techniques used to build individual and group skills, motivate employee performance, and offer opportunities for participation in the decision-making process (Wright \& 
Kehoe, 2008). Such activities revolve around the selection, training, evaluation, compensation and communication of employees with a view to making them tactical and strategic resources for an organization (Godard, 2010; Demo, Martins, \& Roure, 2013; Werner, 2014; Zeidan, 2014).

Different international studies show human resources practices influencing organizational commitment (Whitener, 2001; Chew \& Chan, 2007; Wright \& Kehoe, 2008; Ordaz et al., 2011; Coetzee, Mitonga-Monga, \& Swart, 2014; Al Adresi \& Darun, 2017). Whitener (2001) found that the employee's trust and commitment are strong when he or she perceives support from the organization. Human resources practices are means used for this purpose, and it has been shown that performance evaluation and compensation activities are predictors of organizational commitment. The importance of organizational support contributing to the improvement of employee involvement was also evidenced in the research by Al Adresi and Darun (2017) since the training, performance evaluation and compensation activities, in this order of importance, showed positive correlations with the organizational commitment.

Similarly, Chew and Chan (2007) found that compensation and recognition positively influenced the employee's commitment and desire to remain in the organization. It means saying that the employee tends to be compromised when he realizes that his skills and performance are properly valued. The survey also found that human resources practices, associated with training and career development, influenced the intentions to remain in the organization, but did not necessarily induce employee commitment, contrary to previous studies.

The results found by Chew and Chan (2007) were corroborated by Ordaz et al. (2011) insofar as team skills and the application of performancebased reward systems contributed to affective commitment. Likewise, practices associated with training and compensation positively predicted affective commitment in the study by Coetzee, Mitonga-Monga, and Swart (2014), as well as significantly influencing normative commitment. Harmony with the objectives and values of the organization, as well as the possibility of using talents and skills and being properly rewarded were identified as the elements that strengthened the affective and normative ties.

It is not observed, in the national context, a sufficient number of studies associating the constructs treated here, and it should be noted that, invariably, most of them resorted to the use of the approach of Meyer and Allen (1991). Bandeira, Marques, and Veiga (2000), for example, found in the Post and Telegraph Company (ECT) that all their human resources practices induced 
the affective and normative dimensions of commitment, with weak correlations with continuance commitment. Training and development was the practice that most influenced affective commitment and, together with the practice of career planning, also exerted the greatest influence on normative commitment. The affective and normative types were also the most influenced in the study by Cançado, Moraes, and Silva (2006), which positively impacted by communication and compensation practices and by career development and interpersonal relationship practices, respectively.

More recently, Borges (2013) studied 722 workers in the public and private sectors. The results indicated that communication, well-being, training and development and career planning positively affected organizational commitment. The general results of the survey confirmed findings from previous surveys, which showed civil servants less committed when compared to employees in the private sector. However, differences between the two types of workers in terms of affective commitment have not been verified. Also, more recently, Demo, Martins, and Roure (2013) revealed that the human resources practices of a large bookstore were predictors of organizational commitment and job satisfaction. The indicators of work involvement showed a better prediction for affective commitment, while the compensation indicators had a stronger influence on continuance commitment.

Scheible and Bastos (2013) obtained strong and positive correlations regarding the effect of human resources practices on affective ties maintained with a large Information Technology organization, with emphasis on training and development activities, job security and compensation systems (compensation and benefits). Finally, Jesus and Rowe (2015), when studying the mediating role of organizational justice in the relationship between people management policies and organizational commitment perceived by 415 teachers from a Brazilian federal education institution, found that the affective, normative and continuance commitment were influenced by practices associated with involvement and compensation.

Therefore, the international and national studies discussed here allow, on the one hand, to verify that human resources practices interfere in an affirmative manner the employee's commitment to the organization, enabling the proposition of the following hypothesis:

- H1: Human resources practices are positively related to organizational commitment.

On the other hand, based on this same set of studies, it is recognized that the association between the two constructs reveals a more significant 
relationship between human resources practices and the affective and normative approaches to commitment, providing the formulation of the second research hypothesis:

- H2: Human resources practices have a greater influence on the types of affective and normative commitment when compared to the continuance type.

The next section demonstrates the methodological path followed for the survey and analysis of research data.

\section{METHODOLOGICAL PROCEDURES}

The research is characterized as descriptive (Triviños, 1987), with a quantitative approach (Collis \& Hussey, 2005), using the case study method (Yin, 2010), limited to a large public urban sanitation company. The population consisted of employees working in the 34 municipalities in the metropolitan region of the city of Belo Horizonte, with 900 questionnaires sent to those who held operational, administrative and managerial functions, of which 378 were returned, being 349 considered valid, after a previous analysis of conditions regarding filling out of the answers. Employees at the organization's main headquarters, based in the capital of Minas Gerais, Belo Horizonte, did not participate in the study because they were responding to another survey at the time of the data collection. The sample was defined by a random process, with the expectation of obtaining the largest number of responses to the data collection instrument.

Data collection was carried out in two stages, in this order: documentary and quantitative. The first stage involved the consultation of documents provided by the Human Resources Superintendence (Superintendência de Recursos Humanos - SPRH), for the purpose of understanding the human resources practices carried out by the company. This procedure aimed at creating indicators to compose a scale with the practices employed by it. The scale was of the Likert type of agreement, of five points, composed of 31 statements distributed relatively homogeneously, indicating the practices of recruitment and selection, training and development, compensation, career planning, benefits, performance evaluation, health and safety at work and communication. A pre-test was carried out with a group of employees to refine the scale in form and content.

The second stage resulted from the application of the refined data collection instrument, which was the responsibility of the Division of Human 
and Union Relations (DVRH), which, among other duties, was responsible for conducting research within the organization. The questionnaires were sent and returned via pouch. The instrument was divided into three parts. The first part evaluated demographic and functional data (gender, age group, marital status, number of children, education level, current position, time in the company, time in the current position, salary level and work capacity).

The second part consisted of the reduced and modified scale by Meyer, Allen, and Smith (1993) which contained six indicators for each type of commitment, being affective, normative and continuance. The indicators of affective commitment measured dedication, personal meaning, emotional involvement, identification, integration and desire resulting from work in the organization. The normative commitment indicators assessed feelings of loyalty, obligation, injustice, and guilt for staying or leaving the organization. Finally, the continuance commitment indicators measure the opportunities in the job market, the impossibility, the difficulties or the costs of leaving the organization, the need to continue at work, and the chances of personal disruption in case of job abandonment. A pre-test was also carried out with a group of employees, in order to verify problems in understanding the instrument.

The third part consisted of the scale on human resources practices. The indicators relevant to recruitment and selection verified elements associated with the dissemination and conduct of the internal selection process. With regard to training and development, they appreciated the perception of results, the stimulation of self-development, continuous development, meeting qualification needs and introductory training to functions. Concerning the compensation, the indicators estimated opinions regarding the criteria for profit distribution, wage equity compared to the market, satisfaction with the compensation policy and the knowledge that was perceived from it, and the definition of the compensation criteria adopted by the organization. Regarding career planning, they checked if the organization was successful in developing the employee professionally, the opportunities offered for that, and if the criteria of the promotion system were fair.

Allusive to the benefits, the indicators assessed the level of satisfaction and whether they meet personal needs. Regarding the performance evaluation, they understood the reflexes of this practice on productivity, the estimated criteria, and the link with the professional career guidance. With regard to health and safety at work, the indicators measured the balance between personal and professional life, the adequacy of physical facilities, the conformity and use of work equipment, safety standards and the rele- 
vance of campaigns and programs aimed at the quality of life at work. Finally, the practice of communication was appreciated in terms of agility, transparency and dissemination of information.

The data were submitted to univariate and multivariate statistical analyses. In the univariate analysis, the frequency distribution and also the measurements of position (mean) and dispersion (standard deviation) were used to characterize the profile of the respondents and data related to human resources practices. Then, the reliability test of the variables of the constructs was measured by calculating Cronbach's alpha, which determines how much the items on the scale are interrelated. Soon after, as the data distribution did not meet the assumption of normality, Friedman's nonparametric test was used to assess possible differences between the variables that characterize the surveyed constructs, in order to verify which ones had the greatest impact on the participants of the research.

Multivariate statistics employed multiple regression analysis to identify the human resources practices that most influenced organizational commitment, in view of the formulated hypotheses. Figure 3.1 represents the conceptual model developed.

\section{(Figure 3.1)}

\section{CONCEPTUAL MODEL}

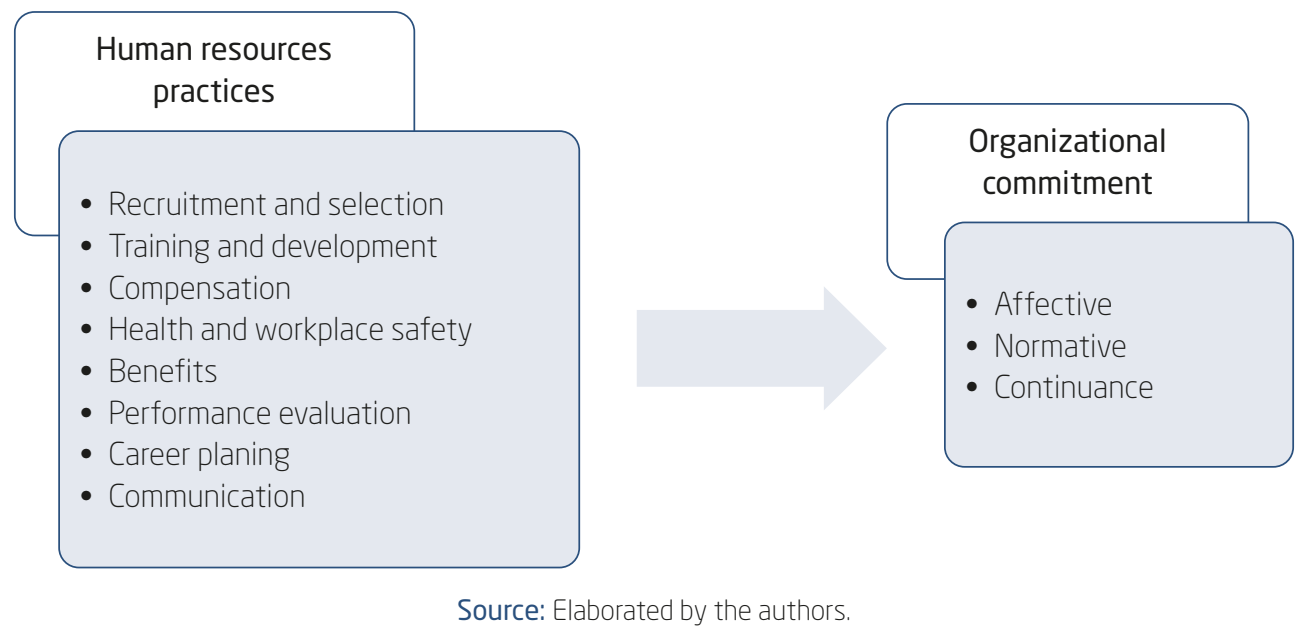

Three guidelines suggested by Hair Jr., Anderson, Tatham, and Black (1998) were established to judge the adequacy of the regression analysis. The first one involved checking the regression determination coefficient 
$\left(R^{2}\right)$. This coefficient varies from 0 to 1 and expresses the intensity with which the independent variables (human resources practices) explain the dependent variables (types of commitment). The higher the value of the coefficient, the greater the explanatory power of the regression equation. The second guideline concerns the degree to which an independent variable is highly correlated with a set of other independent variables. This situation is called "multicollinearity". It is said that it is perfect, that is, it does not impair the effectiveness of the measured parameters, the closer the correlation coefficients get to 1 .

The presence of multicollinearity was verified by means of the Variance Inflation Factor (VIF) measure, assuming that higher measured values, that is, which are very different from 1 , indicate a high degree of multicollinearity, something that, if determined by the analysis, makes inconsistent results. The third guideline relates to the degree to which the relative effect of each variable can be directly compared, independent of the conceptual model on the dependent variable. This assessment was made using the standardized regression coefficient, also called Beta. It is established that the higher the value of this coefficient, the greater the impact of the independent variables on the dependent ones, in terms of explanatory power (Hair Jr. et al., 1998). The research data were processed using the statistical program Predictive Analytics Software (PASW 18). In all the statistical tests performed, those with $\mathrm{p}$ values below 0.05 were considered significant.

\section{PRESENTATION OF RESULTS}

A total of 349 employees participated in the survey, most of whom are male $(84.0 \%)$, over 41 years old $(73.0 \%)$, married $(77.0 \%)$, has children $(80.0 \%)$, with schooling ranging from incomplete elementary school to complete technician (50.0\%), working in the administrative sector $(37.0 \%)$, have worked in the company for over 21 years $(52.0 \%)$ and has a family income of up to four monthly minimum wages (45.0\%).

\subsection{The scores and reliability of the research constructs}

Before showing the scores obtained by the research, it is relevant to highlight the Cronbach coefficients obtained by the analysis, as shown in Figure 4.1.1. 


\section{(Figure 4.1.1)}

CRONBACH'S ALPHA FOR THE INVESTIGATED CONSTRUCTS

\begin{tabular}{lccc}
\hline Human resources practices & Cronbach's alpha & $\begin{array}{c}\text { Organizational } \\
\text { commitment }\end{array}$ & Cronbach's alpha \\
\hline Recruitment and selection & 0.67 & Affective & 0.86 \\
\hline Training and development & 0.86 & & \\
\hline Compensation & 0.67 & & \\
\hline Career planning & 0.82 & Normative & 0.50 \\
\hline Benefits & 0.67 & & \\
\hline Performance evaluation & 0.78 & & 0.68 \\
\hline Health and workplace safety & 0.84 & Continuance & \\
\hline Communication & 0.76 & & \\
\hline
\end{tabular}

Source: Elaborated by the authors.

In general, Cronbach's coefficients were greater than 0.60 in almost all dimensions evaluated, attesting to the reliability of the analysis (Hair et al., 1998). Only the normative dimension, with regard to commitment, showed unsatisfactory reliability (0.50), and this result should be taken with caution. However, this inconsistency could be minimized by the arguments in the literature regarding the possibility of observing a conceptual overlap between affective and normative commitments (Moscon, Bastos, \& Souza, 2012). Regarding human resources practices, it was found that the benefits were the most expressive in terms of the agreement of the role it played for the respondents, while the practice related to the career planning revealed a perception of disagreement. The other practices were positioned in an intermediate zone of agreement. As for organizational commitment, there was a high affection of employees in relation to the organization, compared to the normative and continuance commitment dimensions that did not show significant differences among themselves, tending to an intermediate intensity zone (Figure 4.1.2).

Regarding the identification of a positive feeling on the part of the employees in relation to benefits, it is emphasized that such practice constitutes indirect compensation. The most striking indicators in this regard reveal satisfaction with the health plan offered and the belief that the benefits enjoyed, in general, meet the needs of the employees. It is added that the 
benefits policy practiced is above the average of what is offered by the market and, in many cases, exceeds legal demands, as found in documents made available for consultation. The benefits include, among others: food, education and health, items that are considered relevant to the families' budget.

(Figure 4.1.2)

SCORES FOR THE SURVEYED CONSTRUCTS

\begin{tabular}{|c|c|c|c|c|}
\hline \multirow{2}{*}{$\begin{array}{c}\text { Human resources } \\
\text { practices }\end{array}$} & \multicolumn{4}{|c|}{ Results } \\
\hline & Mean & SD & P-Value & Conclusion \\
\hline Benefits (BE) & 4.00 & 1.06 & \multirow{8}{*}{$0.000^{\star *}$} & \multirow{8}{*}{$\begin{array}{c}\mathrm{BE}>\mathrm{HWS}=\mathrm{CM}>\mathrm{PE}= \\
\mathrm{CS}=\mathrm{RS}=\mathrm{TD}>\mathrm{CP}\end{array}$} \\
\hline Health and workplace safety (HWS) & 3.50 & 1.21 & & \\
\hline Communication (CM) & 3.50 & 1.26 & & \\
\hline Performance evaluation (PE) & 3.33 & 1.35 & & \\
\hline Compensation (CS) & 3.20 & 1.35 & & \\
\hline Recruitment and selection (RS) & 3.00 & 1.35 & & \\
\hline Training and development (TD) & 3.00 & 1.28 & & \\
\hline Career planning (CP) & 2.75 & 1.37 & & \\
\hline \multirow{2}{*}{ Organizational commitment } & \multicolumn{4}{|c|}{ Results } \\
\hline & Mean & SD & P-Value & Conclusion \\
\hline Affective (AF) & 4.00 & 1.09 & & \\
\hline Normative (NO) & 3.17 & 1.26 & $0.000^{\star *}$ & $A F>N O=C O$ \\
\hline Continuance (CO) & 3.17 & 1.34 & & \\
\hline
\end{tabular}

The significance probabilities (P-value) refer to the Friedman test and SD specify the standard deviation. P-value values in bold indicate significant differences.

Significant results were identified with asterisks according to the level of significance, namely: P-value $<0.01^{\text {** }}$ (99.0\% confidence level).

Source: Elaborated by the authors.

The other practices tended towards results that were not entirely convincing, since the averages did not exceed values of 3.50, with a predominant medial tendency of agreement on the part of the employees $(\mathrm{M}=2.75$; $\mathrm{SD}=$ 1.37) regarding elements that foster the career development, indicating the need for attention by the company regarding this practice. Most of the indicators reinforced this feeling arising from the policies applied to the internal 
selection process, self-development, compensation and the promotion process, suggesting that deficiencies in this regard may impair the commitment to be established with the organization (Chew \& Chan, 2007). It is opportune to pay attention to the personal and occupational data identified in the profile of the respondents, such as the high age group and prolonged working time in the organization, standing out as elements that can raise more substantial expectations in terms of career progression opportunities.

It is noted that the employees surveyed are identified and involved with the goals and values of the company, willing to strive for it (Mowday, Steers, \& Porter, 1979) and remain there because they wish that (Meyer \& Allen, 1991). The main affective indicators ascertained are associated with the strong personal meaning that the company represents for employees, with the feeling of belonging to a family, that is, feeling like a person at home and with emotional and integrative involvement with the organization. However, these feelings do not seem sufficient to keep them loyal to the organization, whether in the sense of feeling obliged to remain in the job or the sense of envisioning other opportunities in the market if they left it, since the normative and continuance basis tended towards an average commitment.

\subsection{Testing the research hypotheses}

In order to test the formulated hypotheses, multiple regression analysis was used, which aimed to examine the human resources practices (independent variables) that influenced the types of organizational commitment (dependent variables). Figure 4.2.1 shows the revealed regression model.

(Figure 4.2.1)

REGRESSION MODEL FOR THE RESEARCH CONSTRUCTS

\begin{tabular}{lcccc}
\hline \multicolumn{1}{c}{ Human resources predictors } & Affective & Normative & Continuance & VIF \\
\hline Recruitment and selection & 0.072 & -0.085 & 0.034 & 1.95 \\
\hline Training and development & -0.039 & $0.208^{*}$ & $0.242^{\star}$ & 1.56 \\
\hline Compensation & 0.070 & 0.055 & 0.088 & 2.04 \\
\hline Career planning & $0.357^{*}$ & $0.204^{*}$ & -0.132 & 2.32 \\
\hline Benefits & $0.105^{\star}$ & -0.028 & -0.041 & 1.36 \\
\hline Performance evaluation & -0.035 & 0.033 & 0.052 & 1.99 \\
\hline Health and workplace safety & 0.079 & 0.084 & -0.030 & 1.92 \\
\hline
\end{tabular}


(Figure 4.2.1 (conclusion))

REGRESSION MODEL FOR THE RESEARCH CONSTRUCTS

\begin{tabular}{ccccc}
\hline Human resources predictors & Affective & Normative & Continuance & VIF \\
\hline Communication & 0.079 & 0.055 & 0.064 & 1.99 \\
\hline$R^{2}$ & 0.316 & 0.267 & 0.071 & \\
\hline$R^{2}$ adjusted & 0.300 & 0.259 & 0.049 & \\
\hline$F$ & $19.676^{\star \star}$ & $11.114^{\star \star}$ & $3.250^{\star *}$ & \\
\hline
\end{tabular}

The values placed in the figure correspond to the Beta ( $R^{2}$ and $R^{2}$ adjusted) coefficients calculated by P-value $<0.05^{\star}$ and $p<0.01^{\star \star}(95.0 \%$ and $99.0 \%$ confidence levels).

The acronym VIF refers to the multicollinearity indicator between independent variables, in which high values above 1 indicate the presence of this situation (Hair Jr. et al., 1998).

The $F$ value indicates the intensity and significance of the association between the variables involved in the regression.

It can be seen in Figure 4.2.1 that, among all predictors, the career planning was the most significant (0.357), influencing affective commitment, confirming the studies carried out by Chew and Chan (2007). It is important to note that part of the employees indicated disagreement with the promotion criteria practiced by the organization, suggesting that this result should be looked at carefully. In any case, this relationship pointed to a regression coefficient (adjusted $R^{2}$ ) of 0.30 , denoting an explanatory power tending to fall. The VIF values found suggest that the impact of multicollinearity between human resources practices was not great since the values found are not too far from 1.00.

All significant correlations found exhibited an affirmative sense, allowing the confirmation of $\mathrm{H} 10$ which delimited a positive relationship between the constructs, corroborating a series of studies (Whitener, 2001; Chew \& Chan, 2007; Wright \& Kehoe, 2008; Ordaz et al., 2011; Coetzee, MitongaMonga, \& Swart, 2014; Jesus \& Rowe; 2015, Al Adresi \& Darun, 2017). It is also verified that the greatest number of significant correlations found (Figure 4.2.1), falls on the affective and normative dimensions of the commitment, confirming $\mathrm{H} 2$, which postulated supremacy of these bases over the continuance dimension with regard to the association they maintain with human resources practices, confirming numerous studies carried out (Bandeira, Marques, \& Veiga, 2000; Cançado, Moraes, \& Silva, 2006; Chew \& Chan, 2007; Costa, 2010; Ordaz et al., 2011; Scheible \& Bastos, 2013; Coetzee, Mitonga-Monga, \& Swart, 2014). 
Figure 4.2.1 also shows that the predictor that stood out the most in relation to career planning refers to training and development, showing positive correlations with the types of normative and continuance commitment, in that order of importance. Although the correlations found $(0.208$ and $0.242)$ and the regression coefficient $\left(R^{2}\right.$ adjusted to 0.25$)$ were shown to be weak, some observations can be made regarding these associations. On the one hand, as supported by Meyer and Allen (1991), training and development programs can influence normative commitment. For the authors, employees tend to develop a feeling of obligation in view of the investments that are provided for their professional training.

On the other hand, it is suggested that employee support programs can also increase continuance commitment, especially if what is involved in the relationship is the importance of the work that the employee does in the organization and the difficulty of quitting the job, elements that reinforce permanence in the company due to a need (Meyer et al., 2002). In this situation, the costs and consequences associated with the possibility of leaving the group are taken into account (Meyer et al., 2002).

Although the results obtained revealed positive and more expressive correlations regarding the relationship between human resources practices and the types of affective and normative commitment, Figure 4.2.1 also reveals that continuance commitment showed a weak correlation with almost all human resources practices. Therefore, the little importance of these practices stands out for the continuance of involvement of the employee with the work, confirming previous results (Bandeira, 1999; Borges, 2013) and $\mathrm{H} 2$, which determined supremacy of the affective and normative commitment over the continuance commitment with regard to the association they maintain with human resources practices. About this, it is pertinent to mention Zeidan (2014), when the author argues that individuals, through behaviors of organizational citizenship, spontaneous, voluntary or deprived from material or social rewards, can cause emotional commitment resulting from human resources practices.

\section{DISCUSSIONS AND FINAL CONSIDERATIONS}

With respect to human resources practices, the main result was the high level of agreement perceived by employees with benefits offered by the company, which, in general, seem to meet their individual needs. It should be pointed out the low level of agreement with the possibilities of career development, due to the belief that the promotion system practiced by the company is not perceived as fair. 
The results found by the research revealed a high degree of affective commitment of employees towards the company, contrary to the result found by the study carried out by La Falce et al. (2017), when the authors argued that affective commitment research had suffered a decrease. The findings also differed from foreign and national studies, given that they include normative commitment as a dimension that accompanies the affective commitment in the influence relationship they suffer from human resources practices. Notwithstanding this may be admissible, perhaps due to the current recessive environmental factors in the Brazilian economic reality, the management practices of the researched organization seem to encourage greater involvement of employees with their objectives and problems, led by feelings of belonging, emotional involvement and integration with their values.

Seen from this angle, the desire to be and to remain in the company prevailed among the respondents, corroborating what the literature advocates about the employee's affective involvement with the organization. The normative and continuance commitment presented an intermediate situation between agreement and disagreement, highlighting loyalty, the feeling of gratitude and obligation to the company, with regard to the normative precepts experienced in it.

The results obtained by the applied multiple regression analysis allowed the confirmation of the research hypotheses formulated that postulated, respectively, a positive relationship between human resources practices with commitment and those that predominantly influenced the affective and normative dimensions when compared to the continuance dimension. This evidence corroborates previous findings of other researchers (Bandeira, Marques, \& Veiga, 2000; Cançado, Moraes, \& Silva, 2006; Chew \& Chan, 2007; Costa, 2010; Ordaz et al., 2011; Scheible \& Bastos, 2013; Coetzee, Mitonga-Monga, \& Swart, 2014).

It was confirmed that the predictor relevant to career planning explained the affective commitment of employees to the institution positively. This result, even if it contributed to the confirmation of the positive relationship postulated by the hypothesis, would require an in-depth investigation, once the respondents indicated disagreement with the promotion criteria practiced by the organization. It would also require further research because none of the studies described in this article showed the relationship between career growth and affective commitment. This finding is considered a contribution of the research carried out here, and further studies are recommended to support it. The predictor regarding training and development explained the normative and continuance commitment of the employees positively. In 
contrast, whether in national or international reality, the practice of training and development usually shows a correlation with affective commitment (Bandeira, Marques, \& Veiga, 2000; Scheible \& Bastos, 2013; Coetzee, Mitonga-Monga, \& Swart, 2014; Al Adresi \& Darun, 2017). As another contribution of the present study, it is suggested that training and development programs can influence normative relations with the organization since feelings of obligation would result from investments aimed at the formation of knowledge, skills and attitudes related to functional exercise (Meyer \& Allen, 1991). Although this argument makes sense, future research deserves to be carried out to refine the associations between the constructs treated in this article.

With respect to continuance commitment, no study has been found to support that it is influenced by the practice of training and development, but it is reasonable to admit that support programs spent on employees retract the desire to leave the job, reinforcing the permanence character in the company due to a need (Meyer \& Allen, 1991).

Finally, the predictor associated with benefits positively explained the affective commitment, with the exception that they include improvements for food, education and health, items considered important for the family budget. Initiatives of this nature tend to favor the affective relationship with the organization, but only one study described in this article showed a relationship in this direction (Scheible \& Bastos, 2013). Academically, a part of the findings showed congruence with some studies that pointed out the influence of certain human resources practices on organizational commitment, minimizing the evidence pointed out in the literature, that the results associating such constructs were inconclusive. Career planning practices, benefits, training and development have proven that engagement with work can increase the performance of employees, confirming the findings of several studies already carried out.

Although the results found by the research have offered academic contributions, it is also possible to sustain the diversity of findings evidenced by the studies that theoretically supported the article, signaling that the research theme addressed by this article remains open for future studies, aiming at the consolidation and consistency of the field. It is suggested that contextual particularities of the public and private spheres should also be considered. In addition, the article adds to the few found in the Brazilian context, evidencing the organizational commitment is influenced by human resources practices, despite the fact that the framework of the present study had shown a theoretical range of findings. Still, this study provided consistent indicators to the professionals responsible for the human resources manage- 
ment, helping them to rethink their actions, but without losing sight of the people, those who effectively produce and bolster the development and support of an organization.

For the organization's managers, the results obtained favor a perspective of self-knowledge, maintenance and reassessment of their practices on solid bases, based on the way they are perceived by their subordinates, with a view to making decisions and implementing changes, in line with the strategic planning of the company and the feelings of employees in relation to them, aiming at a humanized policy in people management.

Although methodological care has been used for the development of the study, limiting aspects of research need to be appreciated. It is not possible to conceive statistical generalization for the findings found, once the study was conducted in a single analysis unit and with employees working only in the offices located in the metropolitan region of the capital of Minas Gerais. However, it is acceptable to speak of analytical generalization, that is, to judge that the results obtained can be transferred analogously to the organization as a whole.

In spite of this being pertinent, it is recommended that the observation unit be expanded in the organization for the purpose of consolidating the perceptions regarding the investigated phenomenon, so that future results can envision higher regression coefficients and, thus, strengthen the assumptions that human resources practices effectively influence organizational commitment. In relation to future research, it is suggested to carry out studies in organizations of different business segments or spheres, inspiring the performance of comparative studies. Qualitative research on the investigated constructs is also suggested since the quantitative perspective does not exhaust certain perceptions that sometimes require in-depth treatment.

\section{PRÁTICAS DE RECURSOS HUMANOS E COMPROMETIMENTO ORGANIZACIONAL: ASSOCIANDO OS CONSTRUTOS EM UMA ORGANIZAÇÃO PÚBLICA}

\section{RESUMO}

Objetivo: Este artigo tem por objetivo descrever e analisar a relação entre as práticas de recursos humanos e o comprometimento organizacional em uma grande empresa pública de saneamento urbano. 
Originalidade/valor: Constatou-se que a maior parte das práticas de recursos humanos influencia significativamente o comprometimento organizacional, evidenciando que são as bases afetiva e normativa do comprometimento as mais afetadas e, em uma escala mais fraca, a base de continuação.

Design/metodologia/abordagem: Realizou-se a pesquisa com 349 funcionários, e as hipóteses formuladas foram verificadas por meio de regressão múltipla.

Resultados: Os resultados indicaram o predomínio do comprometimento afetivo dos funcionários, maior concordância com a prática de recursos humanos associada aos benefícios e discordância com o planejamento de carreira no que tange às políticas relacionadas ao processo seletivo interno, ao autodesenvolvimento, à política de remuneração e ao processo de promoção. A análise de regressão múltipla permitiu confirmar as hipóteses postuladas, revelando um relacionamento positivo mais significativo entre as práticas de recursos humanos com os tipos de comprometimento afetivo e normativo quando comparados com o comprometimento de continuação. O comprometimento organizacional do tipo afetivo revelou-se ser influenciado positivamente pelas práticas de recursos humanos associadas ao planejamento de carreira e benefícios, enquanto o comprometimento do tipo normativo se mostrou positivamente mais induzido pela prática de recursos humanos relacionada ao treinamento e desenvolvimento. Não obstante o artigo tenha revelado resultados que contribuem academicamente, futuras pesquisas devem ser realizadas para aprimorar o relacionamento entre os construtos tratados neste estudo.

\section{PALAVRAS-CHAVE}

Comprometimento organizacional. Gestão de pessoas. Práticas de recursos humanos. Condições de trabalho. Organização pública.

\section{REFERENCES}

Al Adresi, A., \& Darun, M. R. (2017). Determining relationship between strategic human management practices and organizational commitment. International Journal of Engineering Business Management, 9, 1-9. doi:10.1177/ 1847979018778374 
Araújo, M. S. G., \& Lopes, P. M. P. R. (2014). Virtuous leadership, organizational commitment and individual performance. Tékhne - Review of Applied Management Studies, 12(1), 3-10. doi:10.1016/j.tekhne.2015.01.008

Ashill, N. J., \& Rod, M. (2011). Burnout processes in non-clinical health service encounters. Journal of Business Research, 64(10), 1116-1127. doi:10. 1016/j.jbusres.2020.11.004

Bandeira, M. L. (1999). Investigando o impacto das políticas de recursos humanos no comprometimento organizacional em uma empresa de serviços do setor público (Dissertação de mestrado, Universidade Federal de Minas Gerais, Belo Horizonte, MG, Brasil).

Bandeira, M. L., Marques, A. L., \& Veiga, R. T. (2000). As dimensões múltiplas do comprometimento organizacional: Um estudo na ECT/MG. Revista de Administração Contemporânea, 4(2), 133-157.

Borges, R. S. G. (2013). The influence of individual, job-related, and organizational characteristics on organizational commitment and the moderation role of public-private sectors. Anais do Encontro de Gestão de Pessoas e Relações de Trabalho, Brasília, DF, Brasil, 1.

Cançado, V. L., Moraes, L. F. R., \& Silva, E. M. (2006). Comprometimento organizacional e práticas de recursos humanos: O caso da empresa XSA. Revista de Administração Mackenzie, 7(3), 11-37.

Chen, S. L. (2017). Cross-level effects of high-commitment work systems on work engagement: The mediating role of psychological capital. Asia Pacific Journal of Human Resources, 2 (1), 1-18. doi:10.1111/1744-7941.12144

Chew, J., \& Chan, C. C. A. (2007). Human resource practices, organizational commitment and intention to stay. International Journal of Manpower, 29(6), 503-522. doi:10.1108/01437720810904194

Coetzee, M., Mitonga-Monga, J., \& Swart, B. (2014). Human resource practices as predictors of engineering staff's organisational commitment. Journal of Human Resource Management, 12(1), 1-9. doi:10.4102/sajhrm.v12i1.604

Collins, C. J., \& Clark, K. D. (2003). Strategic human resources practices, top management team social networks, and firm performance: The role of human resource practices in creating organizational competitive advantage. Academy of Management Journal, 46 (6), 740-751. doi:10.2307/30040665

Collis, J., \& Hussey, R. (2005). Pesquisa em Administração: Um guia prático para alunos de graduação e pós-graduação. São Paulo: Bookman.

Costa, L. V. (2010). A relação entre a percepção de sucesso na carreira e o comprometimento organizacional: Um estudo entre professores de universidades privadas selecionadas da grande São Paulo (Tese de doutorado, Universidade de São Paulo, São Paulo, SP, Brasil). 
Darwish, T. K. (2013). Strategic HRM and performance: Theory and practice. Newcastle upon Tyne, UK: Cambridge Scholars Publishing.

Demo, G., Martins, P. R. M., \& Roure, P. (2013). Políticas de gestão de pessoas, comprometimento organizacional e satisfação no trabalho na Livraria Cultura. Alcance, 20(2), 237-254. doi:10.14210/alcance.v20n2.p237-254

Godard, J. (2010). What is best for workers? The implications of workplace and human resource management practices revisited. Industrial Relations, 49(3), 466-488. doi:10.1111/j.1468-232x.2010.00610.x

Hair Jr., J. F., Anderson, R. E., Tatham, R. L., \& Black, W. C. (1998). Multivariate data analysis. New Jersey: Prentice Hall.

Jaramillo, F., Mulki, J. P., \& Marshall, G. W. (2005). A meta-analysis of the relationship between organizational commitment and salesperson job performance: 25 years of research. Journal of Business Research, 58, 705-714. doi:10.1016/j.jbusres.2003.10.004

Jesus, R. G., \& Rowe, D. E. O. (2015). Percepção de políticas de gestão de pessoas e comprometimento organizacional: O papel mediador da percepção de justiça organizacional. Tourism \& Management Studies, 11 (2), 211-218. doi:10.18089/tms.2015.11226

Karatepe, O. M., \& Demir, E. (2014). Linking core self-evaluations and work engagement to work-family facilitation: A study in the hotel industry. International Journal of Contemporary Hospitality Management, 26 (2), 307-323. doi:10.1108/IJCHM-01-2013-0008

Katou, A. A. (2017). How does human resource management influence organizational performance? An integrative approach based analysis. International Journal of Productivity and Performance Management, 66 (6), 1-49. doi:10.1108/IJPPM-01-2016-0004

Krishnaveni, R., \& Monica, R. (2018). Factors influencing employee performance: The role of human resource management practices and work engagement. International Journal of Business Performance Management, 19(4), 450-475. doi:10.1504ÍOJBPM.2018.095093

La Falce, J. L., Paiva, K. C. M., Muylder, C. F., \& Morais, M. M. S. (2017). Organizational commitment: Longitudinal study in a public higher education organization. Revista de Administração Mackenzie, 18(6), 124-148. doi:10.1590/1678-69712017/administracao.v18n6p124-148

Lyons, S. T., Duxbury, L. E., \& Higgins, C. A. (2006). A comparison of the values and commitment of private sector, public sector, and parapublic sector employees. Public Administration Review, 66 (4), 615-618. doi:10.11 11/j.1540-6210.2006.00620.x 
Maia, L. G., \& Bastos, A. V. B. (2015). Organizational commitment, psychological contract fulfillment and job performance: A longitudinal quantiqualitative study. Brazilian Administration Review, 12(3), 250-267. doi:10.1590/1807-7692bar2015140061

Markovits, Y., Davis, A. J., Fay, D., \& Dick, R. V. (2010). The link between job satisfaction and organizational commitment: Differences between public and private sector employees. International Public Management Journal, 13 (2), 177-196. doi:10.1080/10967491003756682

Meyer, J. P., \& Allen, N. J. (1991). A three-component conceptualization of organizational commitment. Human Resource Management Review, 1(1), 61-89.

Meyer, J. P., Allen, N. J., \& Smith, C. A. (1993). Commitment to organizations and occupations: Extension and test of a three-component conceptualization. Journal of Applied Psychology, 78(4), 538-551.

Meyer, J. P., Stanley, D. J., Herscovitch, L., \& Topolnytsky, L. (2002). Affective, continuance and normative commitment to the organization: A meta-analysis of antecedents, correlates and consequences. Journal of Vocational Behavior, 61, 20-52. doi:10.1006/jvbe.2001.1842

Mithchell, R., Obeidat, S., \& Bray, M. (2013). The effect of strategic human resource management on organizational performance: The mediating role of high-performance human resources practices. Human Resource Management, 52 (6), 899-921. doi:10.1002/hrm.21587

Moscon, D. B., Bastos, A. V. B., \& Souza, J. J. (2012). É possível integrar em um mesmo conceito os vínculos afetivo e instrumental? O olhar de gestores sobre o comprometimento com a organização. Revista Organização $\mathcal{E}$ Sociedade, 19(61), 357-373. doi:10.1590/S1984-92302012000200010

Mowday, R. T., Steers, R. M., \& Porter, L. W. (1979). The measurement of organizational commitment. Journal of Vocational Behavior, 14(2), 224-247. doi:10.1016/0001-8791(79)90072-1

Ordaz, C. C., Cruz, J. G., Ginel, E. S., \& Cabrera, R. V. (2011). The influence of human resource management on knowledge sharing and innovation in Spain: The mediating role of affective commitment. The International Journal of Human Resource Management, 22 (7), 1442-1463. doi:10.1080/095 85192.2011.561960

Paul, A. K., \& Anantharaman, R. N. (2004). Influence of HRM practices on organizational commitment: A study among software professionals in India. Human Resource Development Quarterly, 15(1), 77-88. doi:10.1002/hrdq.1088 
Rai, A., Ghosh, P., Chauhan, R., \& Meht, N. K. (2017). Influence of job characteristics and engagement: Does support at work act as moderator? International Journal of Sociology and Social Policy, 37(1-2), 86-105. doi:10. 1108/IJSSP-10-2015-0106

Reissner, S., \& Pagan, V. (2013). Generating employee engagement in a public-private partnership: Management communication activities and employee experiences. The International Journal of Human Resource Management, 24(14), 2741-2759. doi:10.1080/09585192.2013.765497

Riketta, M. (2002). Attitudinal organizational commitment and job performance: A meta-analysis. Journal of Organizational Behavior, 23, 257-266. doi:10.1002/job.141

Rocha, E. S., \& Honório, L. C. (2015). Comprometimento com o trabalho: O caso dos chefes de seções de infraestrutura da UFMG. Revista de Ciências Administrativas, 21 (1), 237-261. doi:10.5020/2318-0722.2015.v21n1p23

Scheible, A. C. F., \& Bastos, A. V. B. (2013). An examination of human resource management practices' influence on organizational commitment and entrenchment. Brazilian Administration Review, 10(1), 57-76. doi:10.15 90/S1807-76922012005000011

Shahnawaz, M. G., \& Goswami, K. (2011). Effect of psychological contract violation on organizational commitment, trust and turnover intention in private and public sector Indian organizations. Vision, 15(3), 209-217. doi:10.1177/0972262911101500301

Shuck, B., Twyford, D., \& Reio, T. G. (2014). Human resource development practices and employee engagement: Examining the connection with employee turnover intentions. Human Resource Development Quarterly, 25 (2), 239-270. doi:10.1002/hrdq.21190

Suan, C. L., \& Nasurdin, M. A. (2014). Do human resource management practices affect employees' service-oriented organizational citizenship behavior? Evidence from the Malaysian hotel industry. World Applied Sciences Journal, 31 (2), 253-266.

Susanty, A., \& Miradipta, R. (2013). Employee's job performance: The effect of attitude toward works, organizational commitment, and job satisfaction. Jurnal Teknik Industri, 15(1), 13-24. doi:10.9744/jti.15.1.13-24

Tian, A. W., Cordery, J., \& Gamble, J. (2016). Staying and performing: How human resource management practices increase job embeddedness and performance. Personnel Review, 45(5), 947-968. doi:10.1108/PR-092014-0194 
Triviños, A. N. S. (1987). Introdução a pesquisa em ciências sociais: A pesquisa qualitativa em educação. São Paulo: Atlas.

Vermeeren, B. (2017). Influencing public sector performance: Studying the impact of ability, motivation and opportunity-enhancing human resources practices on various performance outcomes in the public sector. International Review of Administrative Sciences, 83(4), 717-737. doi:10.1177/00208523 15591642

Werner, J. M. (2014). Human resource development $\neq$ human resource management: So what is it? Human Resource Development Quarterly, 25(2), 127-139. doi:10.1002/hrdq.21188

Whitener, E. M. (2001). Do "high commitment" human resource practices affect employee commitment? A cross-level analysis using hierarchical linear modeling. Journal of Management, 27, 515-535. doi:10.1016/s01492063(01)00106-4

Wright, P. M., \& Kehoe, R. R. (2008). Human resource practices and organizational commitment: A deeper examination. Asia Pacific Journal of Human Resources, 46(1), 6-20. doi:10.1177/1038411107086540

Wollard, K. K., \& Shuck, B. (2011). Antecedents to employee engagement: A structured review of the literature. Advances in Developing Human Resources, 13(4), 429-446. doi:10.1177/1523422311431220

Yeh, C. M. (2013). Tourism involvement, work engagement and job satisfaction among frontline hotel employees. Annals of Tourism Research, 42, 214-239. doi:10.1016/j.annals.2013.02.002

Yin, R. K. (2010). Estudo de caso: Planejamento e métodos. São Paulo: Bookman.

Zavyalova, E., Kosheleva, S., \& Ardichvili, A. (2011). Human resource management and development practices in indigenous Russian companies and foreign MNCs: A comparative analysis. International Journal of Human Resources Development and Management, 11(2-4), 179-193. doi:10.1504/ ijhrdm.2011.041670

Zeffane, R. (1994). Patterns of organizational commitment and perceived management style: A comparison of public and private sector employees. Human Relations, 47(8), 977-1010. doi:10.1177/001872679404700806

Zeidan, S. (2014). Worker's affective commitment and their willingness to perform discretionary work behaviour: The impact of commitmentoriented human resources management practices. Journal of Business Systems, Governance and Ethics, 1 (1), 13-24. doi:10.15209/jbsge.v1i1.77 


\section{AUTHOR NOTES}

Heloíza H. Oliveira, master from the Master's Program in Administration, Unihorizontes University Center; Luiz C. Honório, Ph.D. from the Center for Graduate Studies and Research in Administration (Cepead), Federal University of Minas Gerais (UFMG) and Birmingham Business School (UK).

Heloíza H. Oliveira is now psychologist in the area of the Psychological Assessment and Human Resources Management and egress from the Unihorizontes University Center; Luiz C. Honório is now full professor and researcher at the Master's Program in Administration of Unihorizontes University Center.

Correspondence concerning this article should be addressed to Luiz C. Honório, Rua Abre Campo, 193/801, Santo Antônio, Belo Horizonte, Minas Gerais, Brazil, CEP 30350-190.

E-mail: luiz.honorio@unihorizontes.br

\section{EDITORIAL BOARD}

Editor-in-chief

Gilberto Perez

Associated Editor

Janaina Macke

Technical Support

Vitória Batista Santos Silva

\section{EDITORIAL PRODUCTION}

Publishing Coordination

Jéssica Dametta

Layout Designer

Editorial Intern

Paula Di Sessa Vavlis

Graphic Designer

Libro

Language Editor

Daniel de Almeida Leão 